\title{
СПЕКТРОФОТОМЕТРИЧНА ДІАГНОСТИКА НЕМЕЛАНОМНИХ ПІГМЕНТНИХ ПУХЛИН ШКІРИ
}

\author{
ㅇ.. Й. Галайчук, О. С. Гоцко
}

ДВНЗ «Тернопільський державний медичний університет імені I. Я. Горбачевського МОЗ України»

РЕЗЮМЕ. У статті наведені результати спектрофотометричного аналізу немеланомних пігментних пухлин шкіри, а саме: пігментних невусів, гемангіом, пігментно базаліоми, себорейного кератозу та ін. Визначено діагностичні спектрофотометричні критері диференційно діагностики немеланомних пігментних пухлин шкіри.

КЛЮЧОВІ СЛОВА: спектрофотометрія, немеланомні пігментні пухлини шкіри.

Вступ. В Укра ні, за даними Національного канцер-реєстру, у 2013 році було діагностовано 3278 нових випадків меланоми шкіри, з них 1919 у жінок і 1359 у чоловіків. Меланома шкіри $є$ причиною смерті понад 1100 осіб щороку [8]. Немеланомних пігментних пухлин шкіри, як от диспластичних невусів, дискератозів, гемангіом, папіломи тощо, $є$ в декілька разів більше, ніж злоякісно меланоми, проте в кра ні не існує єдиного реєстру таких утворів. Перспективною стратегією, направленою на своєчасне виявлення меланоми на стадіях «іn situ», T1-T2 серед різних пігментних утворів шкіри можуть стати сучасні телемедичні технологі та неінвазивні методи діагностики, в т.ч. дистанційна спектрофотометрія $[1,3,5,7,8,10]$. Застосування телемедичних технологій в скринінгових програмах може значно підвищити діагностику меланомонебезпечних пігментних пухлин. На своєчасному видаленні таких пухлин й ґрунтується превентивна хірургія меланоми шкіри [2, 4, 6, 9, 11, 12].

Мета дослідження. Вивчити спектрофотометричні параметри немеланомних пухлин шкіри.

Матеріали і методи дослідження. У дослідження було включено 70 пацієнтів з пухлинами шкіри різного ґенезу та 6 осіб контрольно групи без пухлинно патологі.

Рак шкіри. Обстежено 19 хворих на рак шкіри віком від 51 до 79 років (табл. 1). Чоловіків було 7 , жінок - 12. У всіх пацієнтів діагностовано захворювання на І-й стаді, Т1N0M0

Пігменті невуси. Простий невус діагностовано у 15-х пацієнтів, диспластичний невус - у 12-х, голубий невус - у 4-х. Вік пацієнтів коливався від 24 до 37 років (середній - 31,6 року). Серед обстежених було 20 жінок та 11 чоловіків.

Пігментний себорейний кератоз встановлено у 10 пацієнтів віком від 53 до 76 років (середній вік 64,8 року). Серед обстежених було 7 жінок та 3 чоловіки.

Гемангіоми (венозні та артеріальні) обстежено 10 хворих (чоловіків - 5, жінок - 5).

Контрольні спектрофотометричні дослідження шкіри, які прийняті нами за норму, здійснено у шести осіб - у чотирьох біло раси іу двохнегро дно раси.
У всіх випадках пігментних утворів шкіри застосовували такий діагностично-лікувальний алгоритм: клінічний огляд + цифрова фотографія новоутвору, яка в подальшому використовувалась для спектрофотометрично діагностики; дерматоскопія з цифровою документацією зображення; ультразвукова діагностика: вимірювання товщини, горизонтальних розмірів та об'єму пігментного утвору ( Siemens G60S», L10-5, 7,5-10,0 МГц); спектрофотометрія цифрових зображень пухлин шкіри за допомогою комп'ютерних програм ImageJ, Microsoft Excel; передопераційна цитологічна діагностика пігментних клітин після поверхнево скарифікаційно біопсі; післяопераційна гістологічна діагностика видалених пухлин шкіри.

Спектрофотометричний (СФМ) аналіз цифрових зображень здійснювали за допомогою комп'ютерно програми Image-J, у якій отримували гістограми червоного (R), зеленого (G) і синього (B) кольорів. Далі, в програмі Microsoft Excel створювались RGB-спектрофотограми в шкалі сірого кольору. Оцінювали криві графіків R-G-B кольорів відносно осі абсцис (в одиницях шкали сірого кольору) і осі ординат (висота амплітуди в \%), - ці критері брались за основу диференційно діагностики пігментних пухлин шкіри різного ґенезу [7].

На основі зіставлення доопераційно спектрофотометрично діагностики з післяопераційними патоморфологічними даними визначали валідність запропоновано методики.

Результати й обговорення. Характеристика RGB спектральних графіків нормальних ділянок шкіри у осіб молодого віку (24-25 років), які прийняті за нормальні показники, представлені на рисунках 1, 2.

Спектрофотограми пігментних пухлин шкіри немеланомно етіологі - диспластичного невуса (рис. 3), голубого невуса (рис. 4), пігментно папіломи (рис. 5), гемангіоми (рис. 6), базальноклітинного раку (рис. 7,8 )

Спектрофотометричний аналіз взірців нормально шкіри у молодих осіб показав упорядкований і послідовний розподіл графіків синього (В), зеленого (G) і червоного (R) кольорів на оптичній 
Огляди літератури, ориеінальні дослідження, погляд на проблему

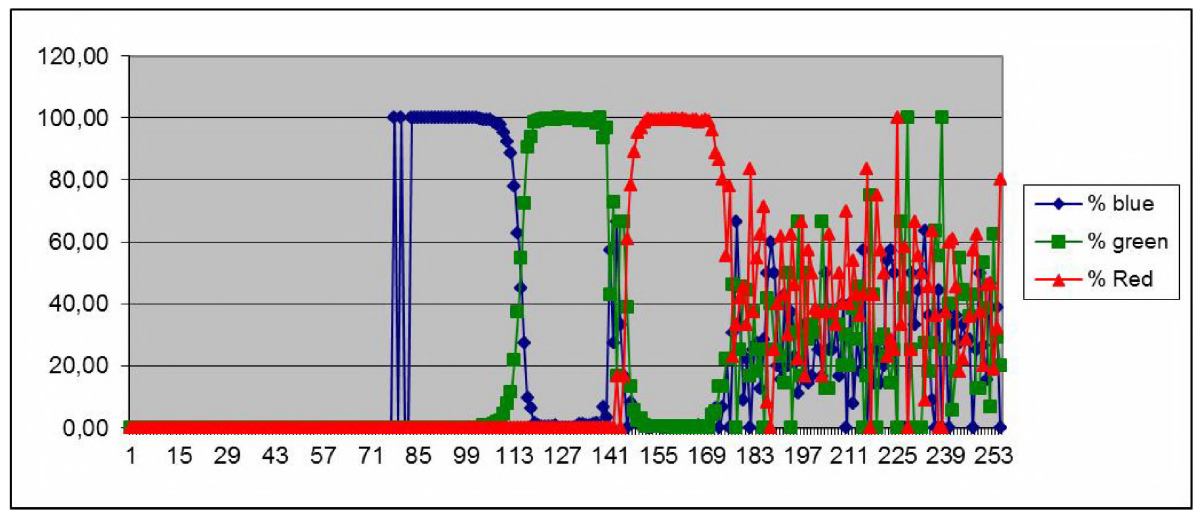

Рис. 1. RGB спектральний графік ділянки шкіри особи біло раси.

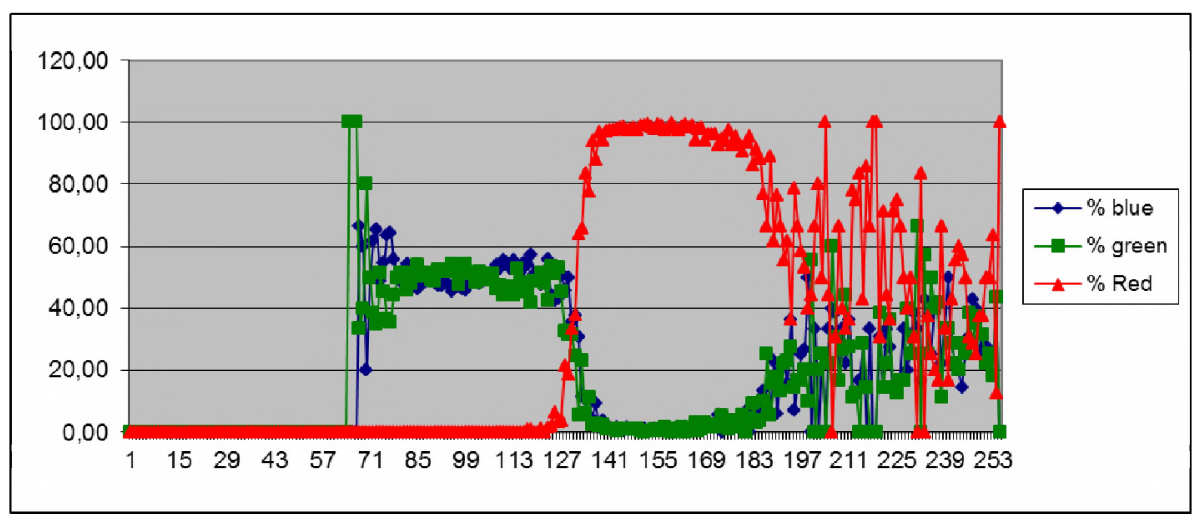

Рис. 2. RGB спектральний графік ділянки шкіри особи негро дно раси.

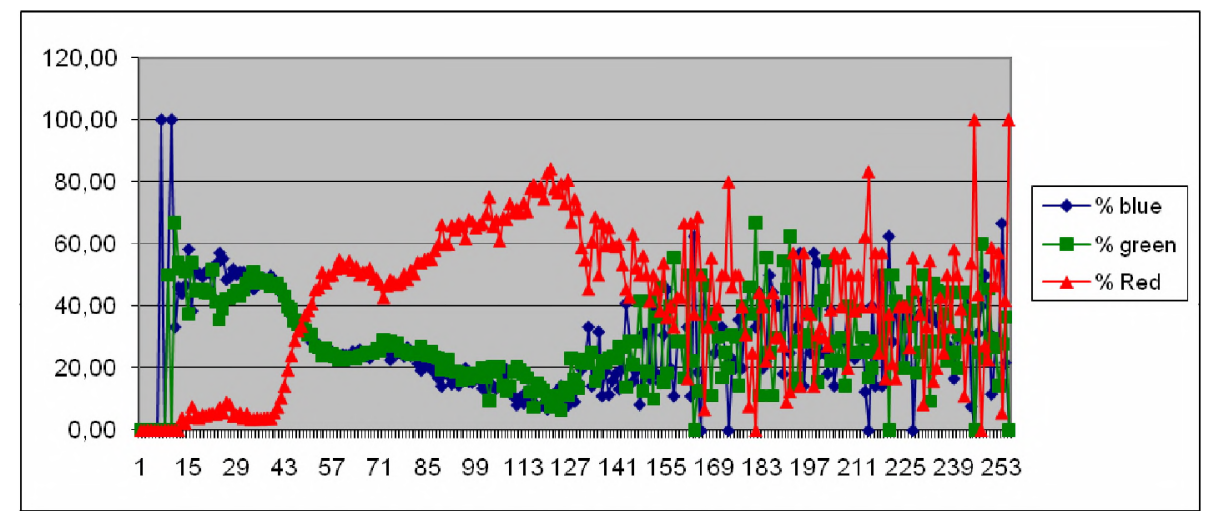

Рис. 3. RGB-спектрограми пігментного диспластичного невуса шкіри.

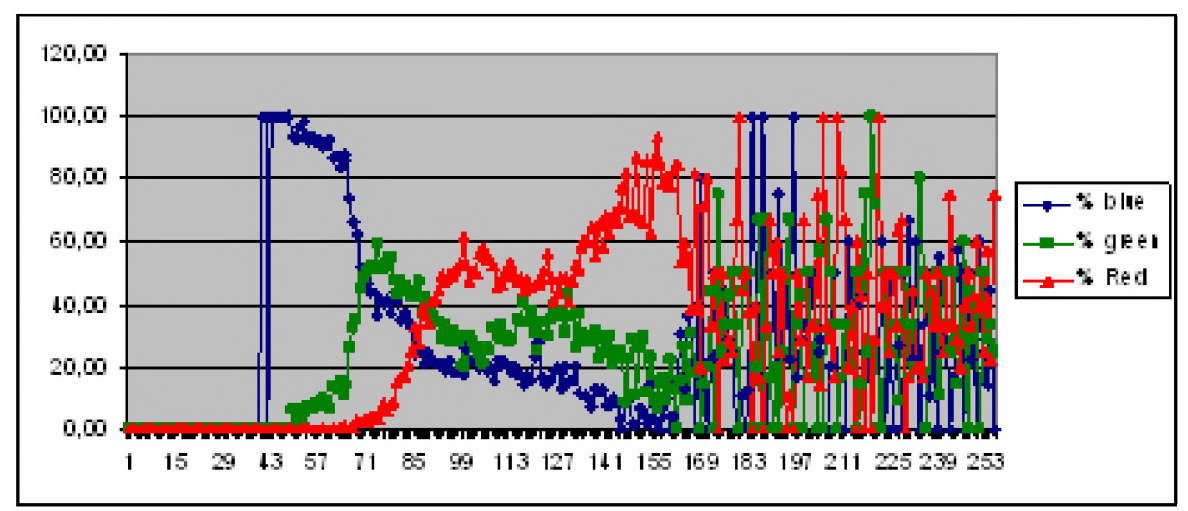

Pис. 4. RGB-спектрограми голубого невуса шкіри. 
Оеляди літератури, оригінальні дослідження, погляд на проблему

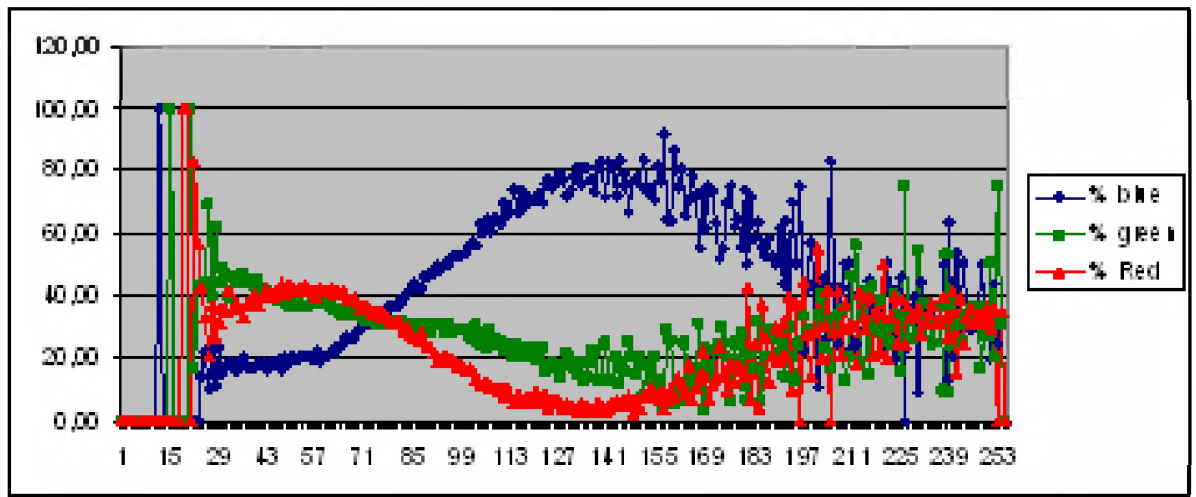

Рис. 5. RGB-спектрограми верукозно пігментно папіломи шкіри.

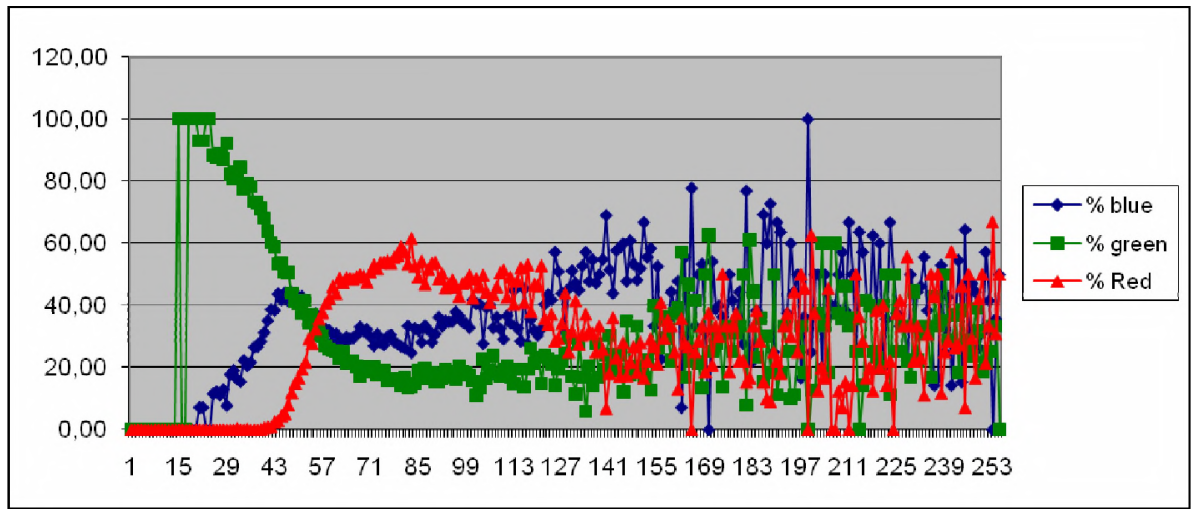

Рис. 6. RGB-спектрограми венозно гемангіоми шкіри.

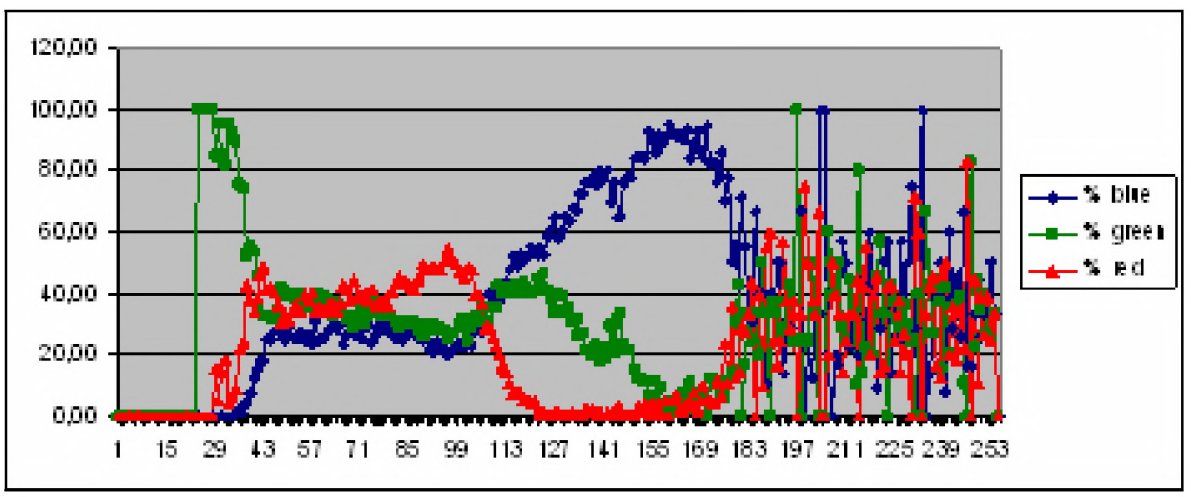

Рис. 7. RGB спектральні графіки пігментного базальноклітинного раку шкіри.

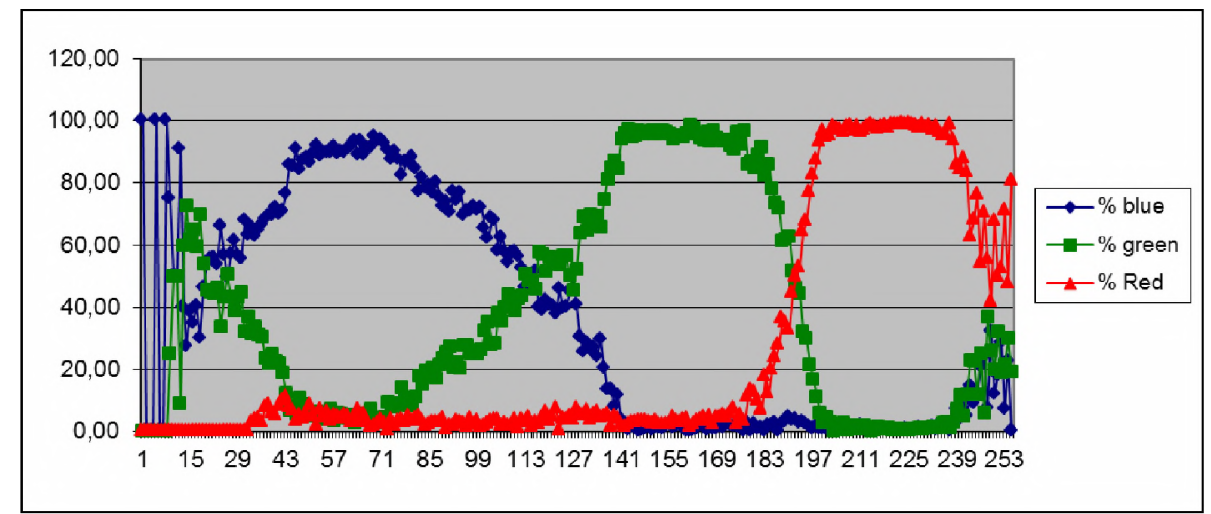

Рис. 8. RGB спектральні графіки безпігментного базальноклітинного раку шкіри. 
Оеляди літератури, ориаінальні дослідження, поеляд на проблему

шкалі сірого кольору. Причому амплітуда всіх кольорів знаходилась на рівні 100,0 \% осі ординат, на якому вони створювали своєрідне «плато» послідовності кольорів - синій, зелений, червоний (по 20 од. шкали сірого кольору кожний). У правій частині шкали сірого кольору, одразу ж після графіка червоного кольору, знаходиться зона затухання амплітуди основних кольорів і накладання неідентифікованих сірих кольорів.

При аналізі взірців нормально шкіри осіб старшо віково групи встановлено розширення зони плато синього і червоного кольорів та зміну конфігураці графіка зеленого кольору, однак всі графіки досягали 100,0 \% по осі ординат. Зона затухання основних кольорів досить незначна, порівняно із шкірою молодого віку.

У осіб негро дно раси RGB графіки взірців шкіри значно відрізняються від біло шкіри. Червоний $є$ основним графіком, його амплітуда $100,0 \%$, а ширина на шкалі сірого кольору майже 40 од. Синій і зелений графіки редуковані й зовсім не відповідають тому формату, як це представлено на графіках біло шкіри. Спектрофотометрія шкіри насичено в нормі меланіном (в осіб негро дно раси) цікава для порівняння з позицій діагностики пігментних пухлин у осіб з білою шкірою.

На основі проведених спектрофотометричних досліджень взірців біло шкіри можна зробити висновок, що в нормі плато графіків усіх основних кольорів знаходяться на рівні $100,0 \%$ по осі абсцис, а для шкіри насичено меланіном основним $є$ графік червоного кольору.

Для базальноклітинного раку шкіри (виразково і нодулярно форми росту) характерні розширені графіки усіх кольорів з амплітудою до 100,0 \% по осі ординат. Пігментна базаліома характеризується максимальною амплітудою червоного кольору до $60,0 \%$.

Пігментні пухлини шкіри (диспластичний невус, голубий невус) мають специфічні графіки червоного кольору з двома амплітудними підйомами. Додатковим критерієм в діагностиці є графіки синього кольору, які починаються зі 100,0 \% відмітки по осі ординат у випадку доброякісно пухлини (диспластичний або голубий невус).

Артеріальні гемангіоми (пухлини, насичені оксигемоглобіном) мають основним червоний

\section{ЛІТЕРАТУРА}

1. Кубанова А. А. Современные информационные технологии в деятельности специализированных дерматовенерологических учреждений / А. А. Кубанова // Вестн. дерматол. и венерологии. - 2009. - № 6. - С. 4-15.

2.Кукушкина М. Н. Меланома кожи: современный взгляд на скрининг, диагностику и лечение / М. Н. Кукушкина, С. И. Коровин, А. Ю. Паливец // Клиническая онкология. - 2012. - № 8 (4). - С. 24-27. графік з амплітудою 80,0-95,0 \% по осі ординат в правій половині шкали сірого кольору (120-240 од.). Графіки зеленого і синього кольорів «переплітались» в лівій частині шкали сірого кольору. Венозні гемангіоми характеризуються низькою амплітудою червоного кольору.

Пігментні дискератози мають окремі послідовні графіки синього (100,0\% по осі ординат), зеленого $(60,0 \%)$ і червоного $(90,0 \%)$ кольорів з короткою зоною «затухання».

Проведені дослідження показали, що спектрофотометричний аналіз цифрових зображень різних пухлин шкіри містить конкретні діагностичні критері для кожно з пухлин, що можна використовувати для дистанційно телемедично діагностики та консультацій.

Висновки. 1. В нормі при цифровій фотометрі шкіри графічне зображення основних спектральних кольорів синього, зеленого і червоного на шкалі сірого кольору в програмі Microsoft Excel представлено послідовно розміщеними прямокутноподібними графіками з амплітудою 100,0\% по осі ординат.

2. Для безпігментного базальноклітинного раку шкіри характерне розширення в 2,0-2,5 раза по осі абсцис графіків усіх кольорів з амплітудою до 90,0-100,0 \% по осі ординат. Спектрофотометричною ознакою пігментно базаліоми $\epsilon$ максимальна амплітуда червоного кольору до 60,0 \% з наступним зниженням.

3. Оптичними особливостями пігментних пухлини шкіри (диспластичний невус, голубий невус) $\epsilon$ специфічні графіки червоного кольору з двома амплітудними підйомами.

4. Для артеріальних гемангіом шкіри характерна інверсія графіків зеленого і синього кольорів у лівій частині шкали сірого кольору, основним $є$ граФік червоного кольору з амплітудою 80,0-95,0 \% на правій половині осі абсцис (120-240од.). Венозні гемангіоми характеризуються низькою амплітудою червоного кольору.

Перспективи подальших досліджень. У перспективі планується продовжити вивчення спектрофотометричних особливостей пігментних пухлин, удосконалення критері в диференційно діагностики доброякісних та злоякісних новоутворів шкіри.

3. Куценко И. В. Использование информационных технологий для оказания дерматологической помощи жителям Донецкой области / И. В. Куценко // Укр. журн. телемедицини та медично телематики. - 2004. - Т. 2 , № 1. - С. 80-84.

4. Модель покращення доступності та якості медично допомоги сільському населенню із застосуванням телемедичних технологій : методичні рекомендаці / 
Оеляди літератури, оригінальні дослідження, поеляд на проблему

О. П. Мінцер, А. В. Царенко, Л. Ф. Матюх. - К. : Укр. центр наук. мед. інформ. та патентно-ліцензійно роботи, 2012. - $26 \mathrm{c}$.

5. Пат. 89831 UA, МПK А61B 1/00, А61B 8/00, А61B 10/00. Спосіб дистанційно диференційно діагностики пігментних пухлин шкіри. Галайчук І. Й., Жулкевич І. В., Гоцко О. С. - № и 2013 15450; Заявл. 30.12.13; Опубл. 25.04.14. Бюл. № 8.

6. Рак в Укра ні, 2012-2013. Захворюваність, смертність, показники діяльності онкологічно служби / під ред. І. Б. Щепотіна // Бюлетень національного канцер-реєстру Укра ни. - К., 2014. - № 15. - 124 с.

7. Степаненко В.І. Телемедицина, теледерматоло гія: реалі та перспективи в Укра ні / В. І. Степаненко, В. В. Короленко //Укра нський журнал дерматологі , венерологі, косметологі . - 2012. - № 4 (47). - С. 19-24.

8. Argenziano $G$. Dermoscopy of pigmented skin lesions: results of a consensus meeting via the Internet / G. Argenziano,
H. Soyer, S. Chimenti // J. Am. Acad. Dermatol. - 2003. Vol. 48. - P. 679-693.

9. Girardi S. Superiority of a cognitive education with photographs over ABCD criteria in the education of the general population to the early detection of melanoma: a randomized study / S. Girardi, C. Gaudy, J. Gouvernet//Int. J. Cancer. 2006. - Vol. 118. - P. 2276-2280.

10. Rigel $D$. The evolution of melanoma diagnosis: 25 years beyond the ABCDs / D. Rigel, J. Russak, R. Friedman // CA Cancer J. Clin. - 2010. - Vol. 60. - P. 301-316.

11. Robinson J. Digital epiluminescence microscopy monitoring of high-risk patients / J. Robinson, B. Nickoloff // Arch. Dermatol. - 2004. - Vol. 140. - P. 49-56.

12. Smith R. Cancer Screening in the United States, 2011. A Review of Current American Cancer Society Guidelines and Issues in Cancer Screening / R. Smith, V. Cokkinides, D. Brooks // CA Cancer J. Clin. - 2011. Vol. 61. - P. 8-30.

\title{
SPECTROPHOTOMETRIC DIAGNOSTICS OF NONMELANOMA PIGMENTED SKIN TUMORS
}

\author{
CI. Y. Galaychuk, O.S. Gotsko \\ SHEI «Ternopil State Medical University by I. Ya. Horbachevsky of MPH of Ukraine»
}

SUMMARY. In article the results of spectrophotometric analysis of pigmented skin cancer, pigmented nevi, seborrheic keratosis, and hemangioma were done. The spectrophotometric criterion for the differential diagnosis of nonmelanoma pigmented skin tumors was defined.

KEY WORDS: spectrophotometric, nonmelanoma pigmented skin tumors.

Отримано 29.01.2015 